\title{
PHILANTHROPIC CLASSISM: AMERICANIZATION AS A CONTROVERSIAL RITE OF PASSAGE IN ANZIA YEZIERSKA'S FICTION
}

\author{
REBECA E. CAMPOS \\ Independent scholar \\ rebecampfe@gmail.com
}

Received 18 June 2019

Accepted 2 December 2019

KEYWORDS: New Woman; Anzia Yezierska; Americanization; Jewish; hybrid identity

PALABRAS CLAVE: Nueva Mujer; Anzia Yezierska; americanización; judia; identidad híbrida

\begin{abstract}
At the turn of the nineteenth century, eastern European Jewish families migrated to America aspiring to fulfil the discourses of upward mobility and religious tolerance widely spread throughout their Russian villages. The Polish-born American writer Anzia Yezierska offers unique sketches of what became one of the most controversial experiences of such a journey: the cultural clash between the already Americanized German Jewish elite and the newly-arrived Russian Jewish women. To gain access to the public space, Yezierska's characters seek social acknowledgement by going through a rite of passage surveilled by German Jewish ladies, who had formerly arrived in the United States. Although the process of Americanization becomes apparently attainable through American philanthropic programs and charity institutions, Yezierska shows how their Americanizing strategies and the models of America $n$ femininity advertised in the period eventually failed to succeed. By developing a hybrid identity, Russian Jewish characters manage to legitimate their cultural differences inside the urban public spaces and beyond the Lower East Side context.
\end{abstract}

\section{RESUMEN}

A finales del siglo XIX, las mujeres inmigrantes judias provenientes de Europa del este dirigieron sus destinos hacia Estados Unidos tras recibir la influencia de los discursos de ascenso social y tolerancia religiosa difundidos a lo largo de las poblaciones rusas. Perteneciente a la segunda ola masiva migratoria hacia Estados 
Unidos la autora polaco-americana Anzia Yezierska rescata en su obra literaria fragmentos de uno de los dilemas más controvertidos de su viaje: el choque cultural entre la élite alemana judia ya americanizada y las mujeres judias recién llegadas desde Rusia. Para acceder al espacio público, sus personajes buscan el reconocimiento social a través de un ritual iniciático supervisado por las mujeres judias alemanas de mayor rango social, que habían migrado a Estados Unidos décadas antes. Aunque el proceso de americanización parece alcanzable a través de sus programas filantrópicos y las instituciones de caridad que regentan, Yezierska muestra cómo sus estrategias de americanización y los modelos de feminidad estadounidense finalmente fracasan. Las protagonistas encontrarán su diferencia cultural legitimada en el espacio público gracias a una identidad híbrida que les permitirá sobrepasar los limites del gueto neoyorquino del Lower East Side.

\section{INTRODUCTION}

During the early decades of the twentieth century in the United States, the need to adopt an American identity led Russian Jewish immigrants to assume a variety of new social standards that would enable them to successfully adapt. To this end, Americanization programs became increasingly relevant as they guaranteed these immigrants rapid assimilation, erasing their stigmatization as low-class newcomers with different cultural backgrounds. Within this context, the Polish-born American author Anzia Yezierska offered an extensive portrayal of Jewish women migrating to America from Eastern Europe at the end of the nineteenth century. Throughout her fiction, Yezierska depicts the cultural clash between the German Jewish elite and the newlyarrived eastern European Jewish women, particularly the unavoidable identity conflict that results when the former migratory group -already Americanized- takes charge of the latter's assimilation to American culture.

The journey from the former Russian Empire to America was not based on random circumstances and decisions, but rather on a drive for survival and the promise of greater opportunity: "They moved westward not only because life was hard under the czar, but because elements of strength had been forged in the Jewish communities and flashes of hope sent back by brothers who had already completed the journey" (Howe 27). Like thousands of Russian Jewish families, Yezierska's parents crossed the Atlantic Ocean 
Philanthropic Classism: Americanization as a Controversial Rite of Passage in Anzia Yezierska's Fiction

immersed in such an idealistic enterprise. Once landed in America, "the Yezierskas were instantly Americanized, receiving as their surname the first name of an older brother, Meyer, who had arrived two years earlier" (Antler 27). Although Anzia became Harriet Mayer, she later decided to stop using this name when she emerged as an author. Her artistic disposition as a writer soon emerged when she depicted the hardships and classist burdens that Russian Jewish women had to overcome in America, which one of her characters, Sara Reisel, describes as "the golden country" (Yezierska The Miracle 115).

At that time, charitable institutions in charge of welcoming eastern Europeans at Ellis Island and providing them with basic consumer goods were predominantly run by German Jewish women who had arrived in New York during the previous migratory wave in the 1870s. Yezierska based most of her stories on the intradiscrimination that she experienced as part of one of the two migratory Jewish groups, which Irving Howe classifies as the "old" immigrants-from North and Central Europe- and the "new" onesfrom the former Russian Empire (51). German Jewish women exercised great influence over the newcomers and, in this position, indirectly fulfilled the expectations of the American middle class: "By the Gilded Age, the German Jewish community had left its peddler roots behind" (Sinkoff 574). Located in the Lower East Side in New York, conversely, Yezierska's Russian Jewish women tend to tackle the process of adaptation by attending the philanthropic courses designed for them by the German Jewish community (Antler 4). Already aware of the need for upward mobility, these German Jewish women also affected the newcomers' adaptation by persuasively spreading an archetype of femininity according to a "white, middleclass model of womanhood" (Ungar 85).

As a direct witness of the Americanizing programs in that period, Anzia Yezierska exhaustively describes in her literary production the duties carried out by philanthropic institutions, mostly consisting of teaching domestic science and supervising its successful realization. In the short story "The Free Vacation House," for instance, an anonymous Jewish mother is persuaded to apply for a charitable program with the hope of upward mobility and temporary rest but, instead, she spends two weeks serving the "rich ladies": 
It was for them that the front from the house had to be always perfect. For them was all the smelling beautiful flowers. [...] Always when the rich ladies came the fat lady, what was the boss from the vacation house, showed off to them the front. Then she took them over to the back to look on us, where we was sitting together, on long wooden benches, like prisoners. (111 Yezierska)

The philanthropic agenda to which Yezierska refers included initial programs in which immigrants would learn domestic strategies related to cleanliness and hygiene (Hoy 88). Furthermore, according to Stephen Pimpare, such Americanization programs were based on scientific principles of discipline and obedience: "Charity organization was determined to apply 'scientific' methods to charity: to make assistance to poor people rational, systematic and coordinated" (48). Yezierska, however, portrays these scientific methods as discriminatory and as a humiliating experience (Berch 149) and, like her characters, sees their failure to master these methods as failure to gain access to Americanness, the longed-for identity that eventually would prevent social stigmatization. The portrayal of the early twentieth-century charitable world appears in Yezierska's fiction as a philanthropic delusion that offers fraudulent validation to the Russian Jewish community. Labeled as "greenhorn" by the German benefactresses in contrast to the "real Americans" (Schreier 50), the newly arrived women also lacked the privilege of acquiring individuality, and were therefore deprived of the possibilities of upward mobility that the German Jewish community already held: "For established immigrants, labeling someone else as a greenhorn was a way of marking progress, because by separating themselves from the mistakes of the newcomer they rose a notch on the assimilation ladder" (Schreier 91).

During the 1890s, new discourses on American femininity began to gain credibility in the Lower East Side, replacing the traditional Jewish female model, which conceived of them as "housewives, deputy husbands, consorts, mothers, mistresses and neighbors" (Nadel and Sarna 24). As part of these new discourses, the American New Woman, for instance, influenced the newcomers due to its emancipatory claims in the hope of equal rights (Patterson, American New Woman 30). With the purpose of widening the strict gender-based philanthropic agenda, particularly interested in reproducing the social role of housewives, Yezierska's characters embrace this new model of American womanhood that would allow 
Philanthropic Classism: Americanization as a Controversial Rite of Passage in Anzia Yezierska's Fiction

them to emancipate from their greenhorn status. The figure of the American New Woman came to refer to those women rejecting their public invisibility and committed to engaging the political arena. Labeled as suffragists, these women were concerned with their inclusion as productive working forces equally acknowledged as men, manifested in their participation in the electoral registry. In response to these new proposals, however, several social groups campaigned against the suffragists, questioning their femininity: "As a suffragette, for example, the New Woman might be called unattractive, barren, neglectful, and manly" (Patterson, Beyond Gibson 27). This characterization, as unflatteringly masculine, was essentially meant to discredit the New Woman's beliefs in gender equality because the real American woman only held legitimacy in a public context insofar as she performed American femininity. Yezierska depicts the influence of the American New Woman in her short story "How I Found America," when the anonymous sweatshop worker denounces a sudden reduction of wages and identifies with the Jewish community she feels entitled to represent: "I entered the boss's office without a shadow of fear. I was not I -the burns of my people burned through me till I felt the very flesh of my body a living flame of rebellion" (116). The character's need for justice confirms the influence that Russian Jewish women received from this emerging model of American womanhood. Similar to the New Woman agenda, Lower East Side women's participation in the labor context would involve their emancipation and their subsequent Americanization in terms of financial independence.

Parallel to the New Woman's incorporation into the contemporary New York social scene, another model of femininity appeared in an attempt to undermine the suffragists' credibility. Standing in opposition to the revolutionary female figure, the "Gibson Girl" managed to establish a feminine image that was more comfortable to the public opinion. Taken from the caricatures designed by Charles Dana Gibson, this image came to be regarded as an accurate and moderate alternative to the problem of the suffragists, whose reputation had been socially undermined: "The Gibson Girl [...] certainly attempted to put to rest any fears of the growing masculinization of American women" (Patterson, Beyond Gibson 38). While the New Woman archetype was exposed to criticism from the most reactionary sectors of American society, the Gibson Girl received wider approval because it was invented as a marketing tool and intended to shape popular culture icons. The 
Gibson Girl reproduced American beauty standards and, therefore, encouraged consumerism. For Yezierska's characters, however, this figure seems inaccessible because of their economic instability and their long working hours, which prevent them from embodying the Gibson Girl's beauty standards.

In Yezierska's stories, the spread of Americanizing discourses based on a standard femininity successfully encourages her main characters to hold high-class aspirations. Influenced by this desire, they do not become aware of their exclusion until they compare their circumstances to those of the German Jewish benefactresses: "The middle-class dream filtered down even to the poorest working girl, who saw marriage and a home as a way to escape from the daily grind" (Baum 233). When Lower East Side women try to acquire social acknowledgement through the path that "Council Women" (Antler 49)-that is, German Jewish benefactresses-have planned for them, they realize how different this path is from what they expected: "Yezierska was a relentless critic of domestic reform efforts in the U.S., faulting the era's settlement houses, working girls' homes, domestic science programs, and model housing developments for their false charity and thinly veiled exploitation of the poor" (Edmunds 408). The creation of an alternative discourse written from their own experiences as Jewish, low-class, immigrant women becomes the only way to avoid the paternalistic delusion inherent to the American models of femininity surrounding these women.

The process of Americanization also played an essential part in persuading the inhabitants from the Lower East Side to erase their Jewishness. Since the imitation of American dress codes and manners were advertised as essential for successful assimilation, a large number of Jewish immigrant women found clothing to be an easy way to be accepted as American in the public space: "Secondgeneration Jewish women also began to try to create another effect: looking 'American"' (Baum 223). Its influence even led to the creation of a conduct guide called Sholem Aleykhem tsu Immigranten ("Welcome, Immigrants"), published in 1903. With the aim of helping immigrants to Americanize, the guide helped the newcomers soften their Lower East Side stigmatization: "the guidebook instructed the immigrants that in the United States a family man could not throw the burden and worry of work upon his wife" (Glenn 77). Yezierska illustrates the conflict between the emergence of new gender-based ethics and traditional Jewishness in an attempt to emphasize the newcomers' difficulty in adopting Americanness. 
Philanthropic Classism: Americanization as a Controversial Rite of Passage in Anzia Yezierska's Fiction

Americanizing discourses demonstrated their effectiveness in the Lower East Side through either the presence of the benefactresses - "friendly visitors" (Yezierska, My Own 244)- or the guides, newspapers, and rags-to-riches stories circulating among the ghettoized neighbors: "The attack upon the Old World stereotype of the 'idle' Torah scholar and his industrious wife [...] came both from German Jewish reformers and from within the eastern European Jewish immigrant community itself" (Glenn 77). For Yezierska's immigrant women, obtaining public recognition implies the acquisition of an American ideal of femininity, which misleadingly would cast their individualities beyond the New York Jewish ghetto. According to Lisa Botshon, Yezierska is said to have brought "a different sense of the New Woman to popular fiction." Entering the public sphere implied that Russian Jewish women attain "selfdetermination, independence, and creative and sexual fulfillment, ideals found throughout many strains of the varied New Womanhood" (234). Yezierska's characters attempt to Americanize by seeking to define their identities according to these female role models-the New Woman and the Gibson Girl. On the one hand, the New Woman focused on fighting for the same rights that were held by American men, while, on the other hand, the Gibson Girl's femininity favored consumerism. However, Yezierska's characters eventually perform a hybrid identity, which involves avoiding the Americanizing programs of the philanthropic institutions.

\section{THE CONCEPT OF THE AMERICAN LADY AND ITS IMPACT ON LOWER EAST SIDE WOMEN}

The emergence of the New Woman as a resistance to traditional femininity was not the only real influence on the women of the Lower East Side. Aside from this unconventional model, the American Lady archetype also affected Russian women who aspired to become Americanized upper-class women. As an alternative to women's domestic confinement, American ladies would focus their social commitment on leading and managing charity-related activities. According to Susan A. Glenn, "The ideal of the lady did not have a universal acceptance among first-generation Jewish immigrants but had a special appeal to those upwardly mobile families who put on middle-class pretensions and to nouveau-riche immigrants, both sometimes referred to as "allrightnicks" (79). In this sense, the "American-born, all-rightniks of the educated world" 
(Yezierska, Salome 92) adopted the prevailing feminine ideal, which certainly involved financial stability to maintain the long-term costs of Americanization. Performing American femininity would confirm their successful assimilation of middle-class standards, distinguishing them from newly arrived Jewish women.

Yezierska consistently depicts situations in which classism becomes the main burden faced by Russian Jewish women in America when they attempt upward mobility and social acknowledgment. In her short stories, characters such as Miss Holcomb in "The Free Vacation House," Miss Whiteside in "Soap and Water," or the friendly visitors in "My Own People" perform the American Lady role to exemplify how Lower East Side women must look or behave if they hope to achieve Americanness.

When Glenn states that "the American lady seemed to have gained the respect, honor, and dignity that many immigrant women wanted for themselves" (79), she reveals the dilemma with which Yezierska deals throughout her literary production. Aspiring to equality and upward mobility, Yezierska's characters struggle and toil in an attempt to afford American femininity, which would give them access to public acknowledgement beyond the Lower East Side. However, when her characters attempt to imitate the American feminine archetype, they realize their impossibility to maintain this identity and inhabit high-class standards without completely detaching from their Jewishness. The identity crisis that occurs eventually makes them aware of their social exclusion and their need of redefining womanhood outside of philanthropic institutions.

Such is the case, for example, with Hanneh Breineh, the main character in the short story "The Fat of the Land." After her three children achieve a high-class status in America, she moves to Uptown, a richer area than her previous settlement house in Delancey Street. Hanneh's identity crisis arises when she meets Mrs. Pelz, a former neighbor that still lives in the Lower East Side and praises Hanneh's new status. The American Lady figure that Hanneh currently represents, however, impedes her from either recovering her Jewish experience or maintaining the American ideal of femininity as a means of self-fulfillment: "I can't talk myself out in their language. They want to make me over for an American lady, and I'm different'." (223) Hanneh's adaptation to a comfortable routine and her dependence on the household servants to articulate domestic dynamics, tasks in which she previously used to engage 
Philanthropic Classism: Americanization as a Controversial Rite of Passage in Anzia Yezierska's Fiction

herself, exemplify the difficulties for Russian Jewish immigrants in adopting American high-class aspirations.

In the same way, Sonya Vrunsky's adaptation to the predominant American Lady's role in Salome of the Tenements demonstrates how difficult it is for Russian newcomers to erase their Jewish cultural background. When Sonya moves to the manor house of John Manning, a wealthy American entrepreneur, and is addressed as "madam" by the domestic service, the young girl feels that she cannot belong to the upper class world. Her Jewishness and low-class status make her inherently empathize with the housemaids working for the Mannings: “The word, 'madam,' made Sonya wince irritably. She, plain from the East Side, to be called 'madam.' [ ...] Everyone there hoped at least to become a somebody. This maid's servile deference was the language of admitted inferiority" (Salome 114). Yezierska's main characters can hardly maintain the American Lady status and so they wander along two cultural worlds apparently impossible to merge. However hard they attempt to imitate that status, their hopes are finally frustrated even after escaping from the Lower East Side influence: "Although many Jewish women aspired to look and behave like American 'ladies', they did not wholly approve of this model of womanhood, frequently considering native women flighty and frivolous" (Glenn 190). Despite Glenn's argument, which explains the reasons why Russian Jewish women eventually dissociate themselves from the standardized American femininity, Yezierska demonstrates the causes of such dissociation from a wider perspective. Characters such as Sonya Vrunsky and Hanneh Breineh are examples of how aspiring to the American lady status leads them to an identity crisis. These characters' attempt to assimilate merely reinforces their inability to adapt through the performance of highclass standards.

The American Lady figure realized itself through the bodies of New York women to such an extent that it allowed them to embrace certain social privileges, such as getting married to elitist and influential magnates or avoiding class stigmatization. In addition, it shaped women's physical appearance so that upper classes could easily recognize their own type with a quick look over women's bodies: "Most Americans considered the 'unwashed' to be the millions of immigrants from southern and eastern Europe who recently arrived in the country's newly plumbed cities" (Hoy 88). Conceiving Americanness in close relationship to cleanliness, American Ladies also valued whiteness and hygiene as an external 
code for gaining access to Americanness. In the short story "The Lost Beautifulness," Yezierska portrays the need of a Lower East Side woman for upper class approval when she decides to spend all her savings on whitening her kitchen: "By day and by night it burned in me the picture -my kitchen shining all white like yours, till I couldn't rest till I done it" (78). Showing off her recently acquired American kitchen does not guarantee, however, her access to upper-class society. Instead, her landlord's increase of rent after noticing her kitchen's renewal forces her inevitable eviction. Another aspect of attaining American Lady status was fluency in English and erasing any eastern-European accents that could reveal the newcomers' cultural origins. Yezierska depicts this means of Americanization in her short story "Where Lovers Dream," in which Sara Reisel is fascinated by an Anglo-Saxon professor whom she randomly encounters: "All the way as we walked along he was learning me how to throw off my greenhorn talk, and say out the words in the American" (146). Either by whitening the kitchen or by learning a fluent English, the realization of the standards of the American Lady would result in effective inclusion in American life without having to work long hours in the sweatshops and factories.

While the American Lady personified the high-class values of whiteness and educated manners, the Jewish woman of the Lower East Side worshipped, conversely, a religious credo based on austerity and daily toil. Judaism could still be felt in the early twentieth-century New York ghetto, which involved the Jewish mothers' duty to maintain the household economy. In this respect, eastern-European mothers did not recognize themselves according to American feminine standards, but instead concentrated their efforts on dealing with their responsibilities as householders and keepers of the Jewish family, which is what Hanneh Breineh eventually wishes to recover: "When I was poor, I was free" (203). Regarding the American Lady as a discursive means to avoid, Jewish women's social alienation and, consequently, gain access to upward mobility and public acknowledgment as individuals, the process of Americanization becomes the main strategy for a successful adaptation. As with the American Lady behavioral codes, Judaism also demands from Jewish women the adoption of certain standards that legitimize their activities as long as they reproduce its traditional values. Provided that ghettoized mothers-like Hanneh Breineh or the anonymous mother in "The Free Vacation House"-were not as influenced by the need for Americanization as their daughters, the 
Philanthropic Classism: Americanization as a Controversial Rite of Passage in Anzia Yezierska's Fiction

benefactresses oriented their courses toward the latter. It thus comes as no surprise that younger women longed to fulfil their dreams about climbing the social ladder: "Jewish women [...] had learned that American 'ladies' were held in high regard by their menfolk and, no doubt, wanted the same for themselves" (Glenn 147). The identity crisis that Yezierska explores in her literary works would therefore be relieved by either remaining in the Lower East Side as low-class religious minorities or by holding a hybrid identity still attached to Jewish cultural backgrounds.

\section{TAKING OVER SOCIAL SIGNIFICANCE: TRANSGRESSION OF THE RITE OF PASSAGE}

To achieve legitimate inclusion in the public space, Yezierska's characters have several options available; however, these options predominantly perpetuate power relations that eventually prevent the characters from succeeding. By regarding the process of adaptation towards Americanization as an identity-shaping path that the characters unsuccessfully undergo, Yezierska's recurrent theme can be analyzed in terms of symbolic rebirth because her Lower East Side characters are required to adopt a new identity in their attempt to fully assimilate.

In her analysis of women's emancipation throughout history, Celia Amorós studies the way power relations emerge through a mutual acknowledgement that individuals in power tacitly agree to perpetuate their privilege. This process of recognizing each other's power cannot take place without a previously arranged rite of passage. The Americanizing discourses that Lower East Side women attempted to perform find an analogy in Amorós' conception of the rite of passage, which 'marks the boys' and girls' access to adulthood" in terms of gender and the awareness of power relations (Tiempo de Feminismo 20). ${ }^{1}$ The temporary transition to which she refers becomes necessary to legitimate something that her characters previously lacked, that is, recognition of their individuality beyond the Lower East Side. Given the great social impact that a rite of passage has for those who hold a higher status -which in Yezierska's stories is represented by the Council Women-, it is necessary to highlight the effects of this symbolic act in terms of class differences: "rites of passage carried out by male individuals [...] just point at the

${ }^{1}$ Celia Amorós' in-text citations are the author's own translations into English. 
access of the generic masculine to the sphere of political power and to the public space" (Tiempo de Feminismo 20). Although Amorós' theory on symbolic rebirths is based on gender inequality, her analytic framework can be extrapolated to the early-twentiethcentury context in New York, because it helps indicate how the dominant discourses of the time established rites of passage that emphasized the discrimination of newly arrived immigrant women against the social validation from the already Americanized ones. It is necessary to accede to the terms of the dominant group in order to gain legitimacy in the public sphere.

In the same way as Amorós refers to women as "identical" ( $L a$ gran Diferencia 89) due to their lack of influence in the public space, Yezierska's ghettoized characters complain about their invisibility, identifying as "nobodies": “What do you mean?' cried Sonya impetuously. 'You, a great philanthropist, to say to me-anybody? There are millions like me'-" (Yezierska, Salome 1). The symbolic rite of passage for the Russian Jewish women involves acquiring American femininity by participating in the Americanizing programs offered by philanthropic institutions. Furthermore, Amorós connects symbolic social rebirth with leaving the maternal realm, thus gaining access to the space of male control: the public sphere (Tiempo de Feminismo 21). Aware of their daughters' intention of becoming assimilated in the new context and leaving the maternal realm, Jewish mothers were often a burden in the process of attaining such acknowledgment (Nadel \& Sarna 26), which Yezierska represents in Sara Smolinsky's mother: “I was known in all villages around not only for my beauty: I was the first dancer on every wedding. You don't see in America such dancing like mine" (Yezierska, Bread 31). Her mother's nostalgia permeates Sara's adaptation throughout the first half of the novel and hinders her urge to Americanize and achieve independence from her family's Jewishness. Sara decides to leave behind her mother's influence in order to become somebody, which connects this symbolic rebirth with Amorós' rite of passage by legitimizing a situation of privilege through mutual acknowledgment.

Similar to some of Yezierska's characters, the Russian Jewish author Mary Antin wished to acquire English-language proficiency to successfully adapt in America. For Antin, mastering English suggests a symbolic rebirth because it enables her to translate herself in America from a newly born language that gives her access to visibility in the public space: 
Philanthropic Classism: Americanization as a Controversial Rite of Passage in Anzia Yezierska's Fiction

Just as the Jewish rite of passage for males has always been oral Hebrew literacy, the recitation of sacred texts in an assembly to mark official entry into the Jewish people, Antin's rite of passage would be a written performance, the publication of her secular life story for a congregation, a nation, of invisible readers to mark her transformation out of the Jewish people. Her rite of passage would be linguistic passing, where erasure of Hebrew and Yiddish would be her submission to the nativist pressures and linguistic policies and practices of her day. (Hana Wirth-Nesser 57)

In addition, when Antin makes use of the third person singular to refer to the stage prior to her arrival in America, she distances herself from her eastern-European upbringing and emphasizes the symbolic function of this rebirth to confirm her successful adaptation and her forthcoming identity: "Now I am the spiritual offspring of the marriage within my conscious experience of the Past and the Present. My second birth was no less a birth because there was no distinct incarnation" (1). Antin's second birth connects with what Amorós describes as a rite of passage towards the mutual acknowledgement of power between individuals holding social privileges. Antin's identity, then, re-defines itself after she appropriates the American values that allow her to shape her experience from an Americanized new discourse: "In these discriminations $I$ emerged, a new being, something that had not been before" (1).

The access of ghettoized women to American identity through the dominant discourses outside of the maternal realm appears legitimate beyond the Lower East Side. This process connects with what Amorós defines as "scheme of adoption," which "takes place when an emerging power, lacking any genealogical legitimacy, is indeed accepted by the previously established power, which tries to make it equivalent a posteriori and to provide it, therefore, with legitimate precedents" (Tiempo de Feminismo 203). In Amorós' words, such displacement involves holding a "legitimate life," whose access "is symbolically conferred to every man because of his relationship with another man-the initiation master-or with men as a whole belonging to his same initiation class, since male individuals gain access [...] as legitimate owners of the power" (21).

Despite Antin's exposure to continuous rebirths in different settings- "Our souls are scarred with the struggles of successive births, and the process is recorded also by the wrinkles in our brains, by the lines in our faces. Look at me, and you will see I have 
been born many times" (72)-what seems relevant to the study of power relations between both German Jewish benefactresses and Lower East Side women is the initiation she went through once she got in contact with the Americanization programs: "Our initiation into American ways began with the first step on the new soil" (146). In the framework of Amorós' maternal realm, the mother represents women's role as deprived of public significance and, thus, prone to social exclusion (like Yezierska's Lower East Side). Antin would be accepting the rupture with the motherly shelter, whose presence prevents her from being reborn and Americanized. In the same way, Yezierska describes that private space as contingent on aspects such as woman's obedience to Judaism, a lack of economic stability, or the constant surveillance from the philanthropic friendly visitors. The transgression that Antin undertakes makes the adoption of the American identity possible through a rite of passage away from any maternal influence.

The need to turn to an initiation master in the process of rebirth reinforces the idea of receiving approval from privileged individuals, which Yezierska's characters constantly seek in the benefactresses and the upper class women: "If you could only give a look how I painted up my kitchen! It lights up the whole tenement house for blocks around" (Yezierska, Lost 76). In addition to Hanneh Hayyeh's interest in Mrs. Preston's approval of her recently painted kitchen, she also seeks validation from her Lower East Side neighbors in an attempt to produce a greater social impact on her transition toward Americanness. Moreover, Hanneh reverses the role of the initiation master as described by Amorós when she invites more identical individuals to acknowledge not only the whitened kitchen but also Mrs. Preston's presence: "Hanneh Hayyeh walked home, her thoughts in a whirl with the glad anticipation of Mrs. Preston's promised visit. She wondered how she might share the joy of Mrs. Preston's presence with the butcher and all the neighbors" (79). Hanneh's legitimate life not only implies Mrs. Preston's acknowledgement of her whitened kitchen, but also her neighbors' witnessing her close relation to an upper-class American Lady, which emphasizes her access to American standards. Although Hanneh seeks validation as a potential American Lady-which Amorós refers to as "the scheme of acknowledgement, by which already existing and genealogically legitimate powers see each other as equally powerful and respect each other as such" (Tiempo de Feminismo 203)-, she fails to maintain the American Lady status due to her lack 
Philanthropic Classism: Americanization as a Controversial Rite of Passage in Anzia Yezierska's Fiction

of economic stability to support an increase in the rent. Hanneh's failure confirms that affluence is inseparable from Americanization.

The mutual acknowledgement of American status strengthens the bonds between Americanized individuals once they mirror each other's privilege. In this regard, Yezierska's Lower East Side greenhorns use Americanization programs and strategies to receive such acknowledgement from upper-class women such as Miss Holcomb, Miss Whiteside, and Mrs. Preston. Moreover, such mutual acknowledgement maintains class differences by offering an American femininity that cannot be sustained on the newcomers' low income. When Sonya Vrunsky wishes to impress John Manning by painting her room and dressing herself up with elegant clothes, she asks the Jewish pawnbroker Honest Abe to lend her one hundred dollars in exchange for paying him back five times that amount as soon as she marries Mr. Manning (Yezierska, Salome 64). The failure of Americanization leads her to an identity crisis because her transition from invisibility toward a position of social power-Amorós' scheme of adoption-does not overcome class boundaries, but rather worsens the characters' ongoing poverty.

According to the critic Irene Billeter, Yezierka's female characters, who "have come to accept that the journey from immigrant to 'Amerikanerin' must not inherently mean the rejection of all the old world baggage, but rather to embrace and transform it, are those heroines who will have most successfully achieved their dreams" (136). The term Amerikanerin therefore refers to the transitory state that Yezierska's main characters undergo when trying to transcend the frontiers of their excluded context. The word shows the ambivalence of their identities, since it merges linguistic fragments from the two languages defining their experiences: American English and Yiddish. In Yezierska's stories, Amerikanerin frequently appears as an identity that the newcomers adopt to emancipate from the Lower East Side. In her novel Bread Givers, published in 1925, Sara Smolinsky is called an Amerikanerin when she tries to persuade her sister Bessie to leave Zalmon, an eastern European immigrant who forces his wife to remain within the domestic sphere: "I got enough trouble on my hands with my own girl going wild! I don't want another Americanerin in my house"' (144). Zalmon's reaction to Sara's intervention reveals the cultural differences between the Jewish tradition, embodied in Zalmon's denial to his wife's inclusion in the American public life, and the modernity Glenn mentions, personified in Sara's attitude defending 
her sister's freedom of choice. Sara's rejection of the model of femininity-that is, domestic confinement and the upbringing of Zalmon's children-is intended to find legitimization because it represents the influence of Americanization.

Likewise Sara, Yezierska's main character in the short story "How I Found America," unwittingly performs that middle-ground identity after failing to fulfil the feminine codes assigned to women of her social status. In this case, it is the factory supervisor who refers to her as Americanerin after she enters his office to denounce a sudden reduction of wages: "I want no big mouthed Americanerins in my shop" (117). Eventually dismissed from her job, the worker's act symbolizes the difficulty in reconciling her disposition towards labor justice and the dynamics of the factory exploitation, or sweatshops, clearly dissociated from the Jewish solidarity she expected. As Katherine B. Payant outlines when referring to Bread Givers' depiction of that identity conflict, "ethnic solidarity" would be "associated with the 'old world'," whereas "individuality" would be "associated with the "new" (19). Therefore, the sacrifice carried out by the young woman would be directly connected with her religious ties, while the boss's determination would represent Americanization. Finding themselves on a middle-ground that claims both economic independence, as is the case in Bread Givers, and justice when claiming fair wages, as in "How I Found America," the protagonists' experiences are publicly exposed after having disobeyed the behavioral codes associated with their greenhorn status.

In this respect, the emergence of a "Jewish immigrant version of New womanhood" (Glenn 208) helps demonstrate the complexity of the characters' adaptation to Americanness beyond the Lower East Side, because it does not only involve imitating the American femininity taught in the Americanization programs. Instead, Yezierska's model of adaptation allows for the maintenance of the newcomers' cultural specificity. Elizabeth Ewen also makes reference to this transition by defining it as a process of metamorphosis that permits the movement from an invisibilized situation to a visible one: "Through observation and contact, through friends and relatives, immigrant daughters learned the vital importance of shedding their pasts. To be a greenhorn was to inhabit a region on the margins of modern life; to overcome being green was a metamorphosis" (67). This metamorphosis validates the new identity from which the individual manages to go through a comfortable assimilation. 
Philanthropic Classism: Americanization as a Controversial Rite of Passage in Anzia Yezierska's Fiction

However, the urge for Yezierska's characters to receive the approval of other Americanized characters -either the German Jewish benefactresses or the American Ladies like Mrs. Prestonposed a significant challenge for them because of their direct proximity to their mothers. Yezierska's eastern European immigrants, along with the young Jewish girls born on American soil, rejected the motherly influence in an attempt to escape from the private context of the Lower East Side. This rejection is depicted, for instance, when Sara Smolinsky reacts to her mother's plea that she visit her family more frequently: “I could see you later. But I can't go to college later. Think only of the years I wasted in the shop instead of the school, and I must catch up all that lost time" (Yezierska, Bread 171). Sara's rejection of perpetuating her former life duties exemplifies the generational gap between Jewish mothers and their recently Americanized daughters.

In addition to the models of femininity so far depicted, Yezierska's characters also progressed towards Americanization by looking up to their fathers or mentors, whose influential position becomes a more appealing role model for them. Janet $H$. Burstein discusses the Jewish women's need in the United States to resort to male individuals' validation to overcome the cultural impositions related to their gender. Taking as an instance Yezierska's novel Bread Givers, Burstein explains why Sara's rejection of her mother takes place, seeking male acceptance instead: "Yezierska's protagonist -like Yezierska herself- seek validation by male surrogates who are not handicapped in America by Orthodoxy or immigrant poverty" (31). Her quest for male approval implies the rupture with the American femininity and leads her to re-interpret her social influence in the urban spaces allocated to male individuals. Following Amorós' argumentation, then, Sara would be calling into question the gendered value system instilled in her to gain autonomy and selfsufficiency: "Emancipating with respect to the situation of subordination passes necessarily for women through a process where they can call into question the generic difference they have been attributed $[. .$.$] and from which [...] they disidentify" (Tiempo de$ Feminismo 19).

On the contrary, the adoption of the values disseminated by the motherly figure would perpetuate Sara's exclusion insomuch as they become useless for the purpose of looking American: "From her mother, therefore, Sara Smolinsky learns the habit of idealizing the 'other who is what she cannot be' and whose recognition enables her 
to realize herself" (Burstein 31). Her father's approval allows Sara the possibility of fulfilling her aspirations for emancipation; this contrasts with the opposition from her mother, through whom Judaism passes down, which is one of the factors motivating maternal influence. Similar to Sara Smolinsky, Mary Antin also expected her father to acknowledge her validity as an individual, which she connects with successfully Americanizing:

In this alliance with the transgressive behavior of her father, Mary begins to carve out what will become her (masculine) immigrant self. Indeed, from the very beginning of her immigrant voyage, Antin's autobiographical narrator imagines herself emulating men not women, and not just any man, but the prototype of the selfsufficient, middle-class, modern man -Robinson Crusoe [...] Later on in the narrative, when Mary is firmly ensconced in American life, she supplements the Crusoe model of solitary male individualism and enterprise with the quintessential American model of male heroism, George Washington. (Payant 5)

Replacing the motherly figure with a male alternative involves the access to all that of which they have been deprived, as women and as Jews. The need for Yezierska's Russian Jewish women to obtain male approval -"dependent on male recognition and similarly validated by her (their) usefulness to others" (Burstein 42)-does not seem completely useful, however, in terms of social visibility. Similar to the figures of the mother or the benefactress, the father or the mentor do not offer the female characters the tools with which they can forge the mechanism of their emancipation.

As an alternative, Yezierska suggests turning to the alreadyAmericanized Jewish community whose lifestyle does not involve rejecting Jewishness. For instance, Sara Smolinsky's eventual relationship with Hugo Seelig, a Polish-born teacher of English phonetics in America, means, for her, fair compensation after struggling to shape her individuality among different male authorities, personified by either her father, Reb Smolinsky, or her upper-class Jewish suitor, Max Goldstein. The pressure of Reb's Judaism as well as Max's elitist individualism results in Sara's urge to bring together both influences and define her identity in terms of cross-cultural amalgamation. This is why Hugo Seelig acts as an identity hinge insomuch as he manages to keep in contact with both experiences and conciliate them. He redefines his identity by creating a valid situation from which he can face the integration in American 
Philanthropic Classism: Americanization as a Controversial Rite of Passage in Anzia Yezierska's Fiction

society while performing his individual difference, which is what Sara eventually feels more comfortable with in her path towards adaptation.

Likewise, Sonya Vrunsky manages her complete adaptation in the public space thanks to the relationship she establishes with Jacques Hollins, who has already rid himself of his previous Jewish name Jaky Solomon. Jacques is presented as a hybrid identity and encourages Sonya to find a middle ground as a solution to her identity conflict: "How different it was being with Hollins, where her work flowed like a song, from those chaotic days wasted with Manning's uplift schemes in his settlement!" (Salome 174). It then becomes impossible for her to successfully assimilate under the influence of John Manning, whose upper-class background and philanthropic nature made him the owner of the Manning Settlement House, where she feels uprooted and an outsider.

Neither, however, do the American feminine models serve as a successful means for Russian Jewish women's adaptation. In another novel by Yezierska, Arrogant Beggar, published in 1927, Adele Lindner seeks acknowledgement not in such male figures but in the female director of the philanthropic Americanizing program that she attends. Understanding the benefactresses as figures of power that are alternatives to the male characters, Adele entrusts her assimilation process to the boarding school's director, Mrs. Hellman. Although her efforts to improve the domestic service quality increasingly receive the benefactresses' acknowledgment, Adele stops longing to become the director's friend, instead increasingly desiring her son's company. Portrayed as a more suitable option from which to be socially acknowledged, Arthur Hellman represents the male gaze that Adele needs to validate her upper-class aspirations. The final substitution of both Americanized characters by Jean Rachmansky, a Jewish musician who became famous after accepting Arthur's help, confirms Yezierska's proposal regarding the necessity of embracing for hybrid identities in order to survive in the American context.

\section{CONCLUSION: RECOGNITION THROUGH HYBRID IDENTITIES}

The quest for social validation recurs in Yezierska's stories as an alternative that allows the characters to uproot themselves from their ghettoized experience in the Lower East Side. Sometimes personified in the father's image, as is the case in Bread Givers, and 
other times seen in the roles of lover or mentor, as with Fanya Ivanowna and Henry Scott in All I Could Never Be (1932), the social acknowledgement becomes essential for Eastern-European immigrants to completely adopt the American identity. According to Amorós' distinction between the identical and the equal, by turning to the approval of males or of German Jewish benefactresses, Yezierska's characters would detach themselves from their former identical condition to successfully gain access to the realm of the equal individuals. However, the cultural and class chasm confirms the unviability of both fatherly and upper-class Americanized Jewish male figures, respectively, when they are proposed as mirrors in which the ghettoized Jewish women seek to be reflected.

Although the process of Americanization becomes a rite of passage by which the invisibilized newcomers presumably achieve the longed-for assimilation, the quest for identity undertaken by Yezierska's main characters is related to the effectiveness with which they reproduce American femininity. As long as they assimilate to any of the American female archetypes so far described, the Jewish women could gain access to the public sphere and pass themselves off as American. However, the symbolic rebirth they wish to undergo eventually fails to guarantee a successful adaptation because the Americanizing strategies, such as clothing or mastering English, imply erasing their Jewish culture and preserve classist philanthropy, two aspirations that Yezierska's characters are unable to fulfill.

With all, Americanization as an assimilative discourse, apparently granted social inclusion because it allowed for the rapid integration of newcomers into American social life as long as they could support it financially. On these grounds, Yezierska offers an alternative, according to which the excluded individual only finds acknowledgement and relief by the side of those characters who share the same social status, as with Sara Smolinsky, Sonya Vrunsky, Adele Lindner, and the anonymous mother in "The Free Vacation House."

The characters' hybrid identities are based on cultural amalgamation by which they legitimate their Jewish background, while participating in the American lifestyle. The acknowledgement of their cultural difference in the public space, however, raises the question of whether their inclusion is legitimated if it has actually been adopted through a class-oriented discourse, like Yezierska's Americanizing programs and charitable institutions. Not defining 
Philanthropic Classism: Americanization as a Controversial Rite of Passage in Anzia Yezierska's Fiction

clearly the extent to which the influence of philanthropic classism legitimates her characters' identities in public American life, Yezierska's stories eventually solve the identity conflict by declaring cultural amalgamation as the only means possible to aspire to Americanization.

\section{WORKS CITED}

Amorós, Celia. Tiempo de Feminismo: Sobre el Feminismo, Proyecto Ilustrado y Postmodernidad. $3^{\text {rd }}$ ed. 2008. Cátedra, 1997.

--- La gran Diferencia y sus pequeñas consecuencias para las luchas de las Mujeres. 2005. Cátedra, 2008.

Antin, Mary. The Promised Land, with an introduction by Werner Sollors. 1912. Penguin Books, 1997.

Antler, Joyce. The Journey Home: Jewish Women and the American Century. The Free Press, 1997.

Baum, Charlotte, Paula Hyman and Sonya Michel. The Jewish woman in America. Dial , 1976.

Berch, Bettina. From Hester Street to Hollywood: The Life and work of Anzia Yezierska. Sefer International, 2009.

Billeter Sauter, Irene. New York City, "Gilt Cage" or "Promised Land"? Representations of Urban Space in Edith Wharton and Anzia Yezierska. Lang, 2011.

Botshon, Lisa. "The New Woman of the Tenements: Anzia Yezierska's Salome." MFS Modern Fiction Studies, Vol. 56, no. 2, John Hopkins UP, 2010, pp. 233-261. 
Burstein, Janet H. Writing Mothers, Writing Daughters: Tracing the maternal in Stories by American Jewish Women. Urbana and Chicago: U of Illinois P, 1996.

Edmunds, Susan. "Between Revolution and Reform: Yezierska's Labor Politics." Modernism-Modernity, Vol. 18, no. 2, John Hopkins UP, 2011, pp. 405-422.

Ewen, Elizabeth. Immigrant Women in the Land of Dollars: Life and Culture on the Lower East Side 1890-1925New York UP, 1985.

Glenn, Susan A. Daughters of the Shtetl: Life and Labor in the Immigrant Generation. Cornell UP, 1990.

Howe, Irving. World of our Fathers: The Journey of the East European Jews to America and the Life they found and made. 1976. Bantam Books, 1980.

Hoy, S. Chasing Dirt: The American Pursuit of Cleanliness. Oxford UP, 1995.

Nadel, Pamela S. \& Sarna, Jonathan D., eds. Women and American Judaism: Historical Perspectives. Brandeis UP, 2001.

Patterson, Martha H. Beyond the Gibson Girl: Reimagining the American New Woman, 1895-1915.: U of Illinois P, 2005.

---, ed. The American New Woman Revisited: A Reader, 1984-1930. New Brunswick, New Jersey, and London: Rutgers UP, 2008.

Payant, Katherine B., and Toby Rose. The Immigrant Experience In North American Literature: Carving out a Niche. Greenwood P, 1999.

Pimpare, S. The New Victorians: Poverty, Politics, and Propaganda in Two Gilded Ages. The New Press, 2004.

Schreier, Barbara A. Becoming American Women: Clothing and the Jewish Immigrant Experience, 1880-1920. Chicago Historical society, 1995.

Sinkoff, N. B. "Educating for "proper" Jewish Womanhood: A Case Study in Domesticity and Vocational Training, 1897-1926." American Jewish History, 77(4), June 1988, pp. 572-599. 
Philanthropic Classism: Americanization as a Controversial Rite of Passage in Anzia Yezierska's Fiction

Ungar, Cara-Lynn. "Discourses of Class and the New Jewish Working Woman in Anzia Yezierska's Arrogant Beggar." Legacy, Vol 16. no. 1, 1999, pp. 82-92.

Wirth-Nesher, Hana. Call it English: The Languages of Jewish American Literature. Princeton and Oxford: Princeton UP, 2006.

Yezierska, Anzia. Hungry Hearts. 1920. Lexington, KY: Forgotten Books, 2010.

---. “The Free Vacation House.” 1920. In Hungry Hearts, 2010, pp. 7-113

---. “The Miracle.” 1920. In Hungry Hearts, 2010, pp.114-141.

---. "The Fat of the Land." 1920. In Hungry Hearts, 2010, pp.178-223.

---. “My Own People.” 1920. In Hungry Hearts, 2010, pp. 224-249.

---. "How I Found America." 1920. In Hungry Hearts, 2010, pp.250-298.

---. Salome of the Tenements. 1923. Illinois UP, 1995.

---. Bread Givers. 1925. Persea, 2003. 